\section{Conflict as the absence of contract}

\section{S. Mansoob Murshed}

$\mathrm{C}$ ivil war is a multi-faceted problem. Not only does it produce human tragedies on a colossal scale, but it creates humanitarian crises that are of concern to the international community, as well as contributing to global and regional insecurity. Civil war is also a major cause of underdevelopment, and perpetuates poverty. ${ }^{1}$ According to the rational choice paradigm, conflict is a result of choice. The rationality may be of a myopic nature, as negotiated settlements avoiding the losses that ensue from war are usually superior from a universal point of view.

In recent years, two phenomena have been utilized to explain conflict onset among academic economists: greed and grievance. The former is due to the influential work of Paul Collier, and is popular among economists. According to this view, conflict reflects elite competition over valuable natural resource rents, concealed with the fig leaf of collective grievance. Above all, there was the assertion that inequality played no part in adding to the risk of civil war. It also provides intellectual excuses for direct, colonial-style intervention to prevent failing states from collapsing. But in many ways, these views go against the grain. There is a long-standing position in political science that relative deprivation and the grievance that it produces fuels internal violence. Identity is also crucial to intrastate conflict. This is due to the collective action problem. It is difficult to mobilize large groups to undertake collective action, because of mutual mistrust, monitoring difficulties, and the freerider problem. Ethnic identities, whether based on race, language, religion, tribal affiliation, or regional differences may serve as the most effective amalgam for the purposes of group formation, compared to other forms of more transient differences that are traditionally stressed such as socioeconomic class. More recently, Frances Stewart has introduced the notion of horizontal inequality, the inequality between groups, rather than the inequality that may exist among an ethnically homogenous population (vertical inequality). ${ }^{2}$

The purpose of this article is to emphasize that violent conflict is essentially a manifestation of the breakdown of the social contract. The three sections of this article examine the greed hypothesis, issues related to grievance, and a synthesis of the greed and grievance views related to malfunctioning institutions that may be described as the failure of the social contract.

The greed explanation for conflict

The greed motivation behind civil war has been popularized by empirical work on the causes of civil war where a cross-section of conflicts in different nations is analyzed econometrically, and greed is proxied by the availability or abundance of capturable natural resource rents. For Collier and Hoeffler, civil wars stem from the greedy behavior of a rebel group in organizing an insurgency against the government. Greed is about opportunities faced by the rebel group. The opportunities can be divided into three components: financing, recruitment, and geography. ${ }^{3}$

The most common sources of rebel finance are the appropriation of natural resources, donations from sympathetic diasporas residing abroad, and contributions from foreign states or multinational companies interested in the region. Natural resource wealth is chief among the three in terms of its relative importance. Recruitment is about the opportunity to induct fighting manpower; something made easier when there is a high proportion of young unemployed males in the population, in a setting of endemic poverty and poor education. Geographical situations favorable to rebel groups are mountainous terrain and other safe havens for insurgents. In short, greed simply means the economic opportunity to fight, and should be distinguished from sociopolitical grievances. Collier and Hoeffler's empirical findings conclude that the set of variables representing rebel opportunity or greed akin to loot-seeking are the main reasons for civil war. By implication, the alternative hypothesis of grievance (justice-seeking) focusing on ethnic or religious divisions, political repression, and horizontal inequality is dismissed, although its invalidity is not formally tested for. Natural resource rents constitute booty and this fact has been used to emphasize the greed or criminal motivation for civil war. Central to Collier and Hoeffler's empirical testing for the greed hypothesis is the role of primary commodities in the economic structure. They measure the dependence on natural resources by the share of primary commodity exports in GDP, and the validity of this metric as well as the statistical robustness of the relationship between resource rents and the risk of conflict, has been called into question. The empirical controversy over the link between natural resource wealth and greed hypothesis are about the saliency of mechanisms in-between natural resource rents and conflict, as well as measurement issues and estimation techniques.

Humphreys for example argues that other mechanisms may be present. ${ }^{4}$ First is the greedy outsider mechanism: the existence of natural resources may be an incentive for third parties - states and corporations - to engage in or foster civil conflict. Second is the grievance mechanism: natural resource dependence could in fact be associated with grievances rather than greed. Third is the weak-state mechanism: natural resource dependent economies may have weaker states, which stems from the nature of state revenue that is dependent on resource rents. On the one hand, untaxed citizens have less ability or incentive to monitor state activity. On the other hand, governments relying more on natural resource revenues than on taxation have weaker 
incentives to create accountable bureaucratic structures.

Any measure of natural resource dependence may also be endogenous to conflict, which has two implications: first, reverse causality, in which civil wars might cause resource dependence by reducing the size of a country's non-resource sector, and second, spurious correlation, where both civil war and resource dependence might be independently caused by an unmeasured third variable such as poor institutional quality.

Observe that in Collier and Hoeffler the term "primary commodity” includes both agricultural commodities and minerals and fuels, but crucially excludes illegal substances (coca and heroin) as well as illegal alluvial diamonds. Certain varieties of resources are more easily captured: they may be lootable such as alluvial diamonds (in Sierra Leone, Angola), available along river beds using artisanal techniques, illicit drugs such as coca in Colombia, or obstructable like an oil pipeline. ${ }^{5}$ Illicit gemstones and drugs are arguably more crucial to financing rogue conflict entrepreneurs in a greed-based conflict; their omission is a serious flaw. Collier and Hoeffler do not differentiate among different types of natural resources such as between lootable and nonlootable natural resources or between point-source and diffuse natural resources. ${ }^{6}$ Lootable point source natural resources in particular are prone to be illegally exploited and traded. Collier and Hoeffler are only concerned with past natural production, neglecting future prospects for extraction. ${ }^{7}$ They also only focus on exports, even though production might be a better measure of the availability of these resources.

On estimation techniques, Fearon provides the strongest challenge to Collier and Hoeffler's empirical finding on the link between primary commodity exports and civil war. He re-estimates Collier and Hoeffler's model using country-year observations, as opposed to country-five year observations employed by Collier and Hoeffler, and finds that the significance of statistical associations between primary commodity exports and civil war onset vanish in the country-year regression, meaning that the previous claim of such a relationship is simply not robust. In other words, this crosscountry result will not withstand variation in sample and data coverage. A similar view is shared by Ross who reviews 14 cross-country empirical studies on natural resources and civil war. He concludes that the claim that primary commodities are associated with the onset of civil war does not appear to be robust, oil dependence appears to be linked to the initiation of conflict, but not its duration, and illicit gemstones and drugs seem to lengthen pre-existing wars. ${ }^{8}$

There are additional reasons to be skeptical of the greed theories. First, they generally neglect the destructiveness of war, and its capacity to ravage productive capacity, additional to direct military expenditure. Second, there is no growth in these models, something which would raise the opportunity costs of war. Third, the possibilities of peaceful exchange need to be limited in order to rationalize conflict. In traditional economics the gains from trade arise mainly from differences in tastes, technology, and endowments, and these gains from trade need to be minimized in order to make conflict an optimal choice. Violent means are attractive when the intention is to extract resources (as in the case of colonial plantations and mines) or accumulate surpluses at the expense of others (mercantilism). Fourth, these models imply full information. In the presence of asymmetric information, misperceptions about contest success, the opposition's intentions, and so on, wars that do not maximize expected utility under full information may break out, akin to problems associated with moral hazard and adverse selection. Fifth, such theorizing is broadly blind to institutions and the presence of transactions costs that breed mutual mistrust Wars can also reflect the absence of institutions facilitating negotiation and peaceful exchange.

Despite these limitations, there is much in these models that can explain the greedy behavior as analyzed by the empirical exponents of the greed hypothesis. First, the presence of readily capturable natural resource based rents may make conflict more attractive when compared to peaceful production, as can a shortage of intermediate inputs due to population pressure. These resources are best regarded as a non-produced "prize" such as oil or diamonds (which apart from extraction costs are like manna from heaven), whose ownership is violently contested. Second, contributions from a sympathetic diaspora (or aid from a superpower in the Cold War era) can raise the probability of victory of a potential rebel group against the state. Third, the inability of the state to act as a preemptive leader in a potentially divided nation may raise the chances of war between groups in a manner similar to the weakstate capacity mechanism discussed above.

\section{Grievances and horizontal inequality}

Central to grievances is identity and group formation. An individual's utility may be related to his identity, specifically the relative position of the group he identifies with in the social pecking order. ${ }^{9}$ An individual may derive utility from certain normative forms of behavior appropriate to his identity but considered deviant by other groups and may even face sanctions from like-minded group members if he deviates from them. This type of behavioral paradigm may be related to solving the collective action problems without which organized large-scale violence is impossible, even if we believe conflict is primarily motivated by greed. As noted, some appropriate definition of ethnicity may be a superior basis for group formation compared to social class in an ethnically homogenous society. We may subdivide theories of grievance into relative deprivation, polarization, and horizontal inequality.

\section{Relative deprivation}

The notion of relative deprivation dates back to the work of Ted Gurr who defines it as the discrepancy between what people think they deserve and what they believe they can get, in short the disparity between aspirations and achievements. ${ }^{10}$ Thus, educational achievements may raise the aspirations of young people, but they will 
(C) www.epsjournal.org.uk - Vol. 4, No. 1 (2009)

become frustrated if unemployed, occasionally venting their feelings in mass political violence.

\section{Polarization}

A related notion is that of polarization. It occurs when two groups exhibit great intergroup heterogeneity combined with intragroup homogeneity. Economic polarization (along with high vertical income inequality) can occur in societies that are culturally homogenous. Ethnic polarization could, in principle, exist along with a degree of economic equality. What is useful is a hybrid concept that combines identity and economic polarities, as in Østby. In their original and seminal concept of polarization, Esteban and Ray focus on the identification and alienation framework. Their idea is that polarization is related to the alienation that groups of people feel from one another and that such alienation is fueled by the feeling of within-group identity. Furthermore, they argue that traditional measures of inequality are only concerned with interpersonal alienation, but fail to capture the dimension of group identity. It is important to note that ethnic polarization requires two or a few ethnicities. When a society has a very large number of identities, then the term ethnic fractionalization is more appropriate. Therefore, polarization is what may matter for conflict, rather than fractionalization, and/or overall vertical (inter-individual) inequality. Montalvo and Reynal-Querol find that ethnic polarization is a significant explanatory variable for civil war onset while ethnic fractionalization is not. ${ }^{11}$

\section{Horizontal inequality}

The notion of horizontal inequalities among groups, classified by ethnicity, religion, linguistic differences, tribal affiliations, and so on, is thought to be an important cause of contemporary civil war and sectarian strife, but not routine violence. The idea of horizontal inequality may overlap with the notion of relative deprivation and polarization as will be indicated by alternative measures discussed below. The horizontal inequality expression originates from the work of Frances Stewart and is distinguished from vertical inequality, which is the inequality within an otherwise homogenous population. ${ }^{12}$ Four sources of horizontal inequality may be highlighted:

- Discrimination in public spending and taxation: discrimination in the allocation of public spending and unfair tax burdens can cause unrest.

- High asset inequality: agrarian societies with high inequality, for example El Salvador, Guatemala, Nepal, the Philippines, and Zimbabwe, have high asset inequality and are very prone to conflict.

- Economic mismanagement and recession: conflict-ridden countries have usually suffered prolonged economic mismanagement and growth collapse. Economic mismanagement is often associated with an uneven and unfair distribution of the burdens of subsequent adjustment; public spending benefitting the elite and the military is protected, often favoring particular ethnic groups, with the burden of adjustment placed on expenditure of value to the poor and disadvantaged groups. - Grievances related to resource rents: natural resource rents can by themselves become a source of grievance if local populations feel that they are not getting a fair share of these, as in the Niger Delta region of Nigeria.

Relative deprivation and horizontal inequalities have been found to significantly affect conflict in Nepal and Indonesia, to cite two examples of its application to individual nations. Østby manages to construct polarization indices and horizontal inequalities across 36 developing countries for 1986-2004 based on ownership of consumer durables and educational attainment from household surveys. In her panel and crosssectional analysis, she finds that social and economic polarization and social horizontal inequality based on education significantly contribute to conflict, whereas vertical inequality and purely ethnic or socioeconomic polarization do not. A priori one would expect more enduring horizontal inequalities based on health, education, political exclusion, and asset holdings to be more significant as compared to transient income differences. ${ }^{13}$

Three further points are worth emphasizing at this juncture. First, horizontal inequality has to be measured at the level of the nation-state. In a sense it refers to cross-sectional variation within a specific country. The data in different countries on horizontal inequality is still embryonic. Indices for horizontal inequality can be used for cross-country comparisons, whereas for a single conflict onset, gap measures may be sufficient. Second, most nation-states do not keep detailed or systematic data on group inequalities (say between Catholics and Protestants, Hutus and Tutsis, Muslims and Christians) because of obvious political sensitivities. However, ethnic questions in future household surveys across the developing world will go a long way in helping us to enumerate data on inter-group differences in socioeconomic achievement. Third, horizontal inequality as a cause of conflict can work in two directions: the rich may initiate conflict to extricate themselves from the relatively poor (the rage of the rich), or the poor may rise up in revolt against the rich (the rage of the poor). The former may be more likely in cases where a region suddenly discovers it can exist viably on its own resources, thus wishing to secede and not hand over revenues to the rest of the country. The latter is likely to be manifested in rebellions and revolutions.

Synthesis and social contract

The greed versus grievance dichotomy is a useful entry point into the debate about the causes of conflict. In certain instances, where there are substantial quantities of capturable natural resource wealth present such as alluvial diamonds, oil, or drugs, greed may be the dominant factor prolonging conflict, but without group formation (for which some historical grievances are important) violent collective action cannot 
take place. Although greed and grievance are regarded as competing views, yet they may be complementary. Greed may produce grievances after war breaks out as people are affected by conflict, and the converse is also true as movements that begin by espousing a grievance-based cause may become used to exacting rents from the populations that they control or the diasporas and other support groups that back them. The greed or grievance explanations (or some hybrid form of both) may be necessary for the outbreak of civil war, but arguably they are not sufficient. This is because the causes enumerated in the preceding two sections contribute to the risk of civil war, yet some societies despite having conditions predisposing them to civil war, such as horizontal inequality, polarization, and natural resource rents, do not descend into conflict. It can be argued that for the forces behind either greed or grievance to take the form of large-scale violence there must be other factors at work, specifically a weakening of what may be described as the social contract following classical thinkers such as Hobbes, Locke, and Rousseau among others. ${ }^{14}$ This is similar to the weak-state capacity, and by implication poor institutional quality, arguments made before. Therefore, even if rents from capturable resources do constitute a sizeable prize, violent conflict is unlikely to take hold if a country has a framework of widelyagreed rules, both formal and informal, that govern the allocation of resources, including resource rents, and the peaceful settlement of grievances. A viable social contract can be sufficient to restrain, if not eliminate, opportunistic behavior such as large-scale theft of resource rents, and the violent expression of grievance.

Civil war is a reflection of the breakdown or degeneration of a contract governing interactions between various parties. Hirshleifer draws our attention to the fact that within a society, social contracts can be vertical if they are authoritarian in the sense of Thomas Hobbes, or they may be horizontal if fashioned with popular consent, as advocated by John Locke. The former may be described as dictatorial, and the latter as democratic. ${ }^{15}$

\section{The breakdown of social contract}

What factors lead to the breakdown of the social contract within a nation-state? What circumstances create incentives for groups within societies to choose war rather than resolve disputes peacefully? Clearly these seem to occur in failing states. Yet, the term "failed state" may be too vague and unhelpful in this regard. Among the various factors, three reasons may be highlighted. The first refers to the fiscal and revenue sharing agreements the state (or those in power) have with various stakeholders, and the breakdown of these arrangements can produce greed and/or grievance. Second, there is the political system. In the face of an unstable polity where the separation of powers and the sources of (legitimate or illegitimate) power are inherently unstable, it is important to focus on individual incentives faced by rulers that may or may not cause them to promote development and modernization. Third, the famous Lipset modernization hypothesis states that demands for democracy surely follow economic development and the attainment of a high standard of living; once a particular (high) level of average income is achieved violence becomes a very costly means of settling disputes. The road to peace and democracy is therefore along sustained economic growth, and, thus, the real culprit as far as the breakdown of the social contract is considered could be growth failure in low-income developing countries

because it creates conditions where violence is more attractive. Low growth also implies a more undiversified economic structure, susceptible to terms of trade shocks and dependence on external aid. ${ }^{16}$

Within nation-states, the fiscal system will secure a workable social contract if the allocation of public expenditure and the apportionment of taxes are judged to be fair, or at least not so unfair that some groups judge taking resources by force the better option. There are many examples of conflicts emerging out of fiscal disputes. Disputes over the apportionment of revenues from natural resources are especially common and, as in Indonesia and Nigeria, these take on ethnic and regional dimensions. Contemporary civil wars are more often related to the breakdown of explicit or implicit arrangements to share resources, rather than their complete absence (although in certain instances such as with the discovery of new minerals or fuels a revenue sharing agreement may not have been devised). One reason that a contract to share revenues encounters difficulties is the imperfect credibility with which the side that controls the "pot" honors its commitment, due mainly to malfunctioning institutions and political malfeasance.

Conflict-affected nations have histories of weak social contracts (or a once strong social contract that has degraded). This weakness is in many instances a legacy of colonialism that institutionalized mechanisms favoring settlers over indigenous peoples (Guatemala, Zimbabwe, South Africa); divide-and-rule favoring one ethnic group over another (as in Rwanda); market controls to create rents for settlers to the cost of locals (Zimbabwe); and the expropriation of land and resource rents (Angola, and the Belgian Congo).

Anocracies

Hegre et al. point out that the risk of conflict is lower in both well-established democracies and autocracies. They suggest that conflict risk is at its highest during transitions to and away from democracy when state capacity is weak, and also in fledgling and imperfect democracies (anocracies). Most developing countries are 
imperfect democracies, or at any early stage of the democratic transition. A final complexity in fatally weakening social contracts was the interaction of these "domestic" factors with external events, notably the Cold War that provided finance and ideological succor to ruling elites and rebels. The net result of these processes is the accumulation of grievances within the context of a disintegrating social contract that would otherwise have provided the rules of the game to govern distribution and to achieve peaceful conflict resolution. These circumstances can also promote greedbased motivations aimed at controlling natural resources. ${ }^{17}$

Pure versions of the greed hypothesis are, on their own, unsatisfactory explanations for the causes of conflict. Addison, Le Billon, and Murshed construct a game-theoretic model of contemporary conflict involving the competition for resources combined with historical grievances. ${ }^{18}$ In addition to resource rents, grievances also play their part in fueling conflict by explaining intergroup noncooperation and serving to lower the cost of participation in conflict. Conflict can increase because of heightened intrinsic grievances, or because there are more lootable resources. In reality, the competing greed versus grievance hypotheses may, after all, be complementary explanations for conflict. Insofar as they do provide alternative views, a fair test for their relative explanatory powers is best conducted at the level of a quantitative country-case study, because cross-country comparisons of horizontal inequality are still at very early stages of development due to the lack of data.

Indonesia's resource rich regions that have had separatist conflicts with the federal government offer us a striking contrast in trying to gauge the relative explanatory power of the greed versus grievance explanations for conflict. When viewed via the lens of a detailed quantitative case study, the grievance and horizontal inequality explanations dominate any greed motivation. ${ }^{19}$ Yet, when looked at as one observation among many through the prism of a cross-country study, Indonesia's resource-rich regions are examples of a modified form of the greed explanation (resources helping to prolong the duration of conflict and encouraging secession. ${ }^{20}$ It would appear, therefore, that the greed explanation for conflict duration and secessionist wars works in cross-country studies, but has to make way for grievance-based arguments in quantitative country-case studies. Grievances and horizontal inequalities may, after all, be better at explaining why conflicts begin, but not necessarily why they persist. Neither the presence of greed or grievance is sufficient for the outbreak of violent conflict, something which requires institutional breakdown and the failure of the social contract.

As yet, no empirical models at the level of cross-national analysis exist to properly test for the relative power of greed vis-à-vis horizontal inequality type grievances in explaining conflict onset. This is not just a result of constraints posed by insufficient data. Greed and grievance can and do coexist. Because one breeds the other, a model of their simultaneous determination is required, along with the contribution of poverty (which is chiefly about the lack of growth) and institutional quality. Furthermore, the existing econometric literature regarding the causes of conflict allows us to infer little about the true nature of the causal links between the phenomena examined. Tests for causality require sufficiently long time-series data; unless techniques of dynamic panel data analysis are employed, inferences about causality will remain limited in nature.

Despite these shortcomings, a review of the existing empirical literature on the causes of conflict informs us that the most robustly significant predictor of conflict risk and its duration is some indicator of economic prosperity (or lack of poverty) such as income per capita within a cross-section where average income does vary. This is because at a higher income people have more to lose from the destructiveness of conflict; ${ }^{21}$ and higher per capita income implies a better functioning social contract, institutions, and state capacity. Yet economic development, even if it eventually diminishes motives for conflict, may at first increase violence in poor institutional settings, if growth is not pro-poor and disadvantages some groups, as Tadjoeddin and Murshed have demonstrated for Indonesia. ${ }^{22}$ Above all, there is less poverty; masses of impoverished individuals provide the best recruitment grounds for rebel fighters. Ultimately, the political economy of growth failure and institutional degradation must inform us about the causes of conflict, along with theories of deprivation and alienation.

Notes

Syed Mansoob Murshed is at the Birmingham Business School, University of Birmingham. He also holds positions at the Institute of Social Studies, The Hague, and at the Center for the Study of Civil War (CSCW), Peace Research Institute, Oslo. He may be reached at murshed@iss.nl. Financial support from the European Unionfunded MICROCON project and the suggestions of a referee are acknowledged.

1. See Collier, et al. (2003); Collier (2007).

2. Greed: e.g., Collier and Hoeffler (2004); relative deprivation: Gurr (1970); collective action: Olson (1965); horizontal inequality: Stewart (2000).

3. Collier and Hoeffler (2004).

4. Humphreys (2005).

5. See, e.g., Ross (2003) on these issues.

6. Lujala, Gleditsch, and Gilmore (2005); Murshed (2004).

7. Humphreys (2005). 
8. Fearon (2005); Ross (2004).

9. Akerlof and Kranton (2000); Sen (2006).

10. Gurr (1970).

11. Esteban and Ray (1994); Østby (2008); Montalvo and Reynal-Querol (2005).

12. Stewart (2000).

13. Nepal/Indonesia: Murshed and Tadjoeddin (2008); indices: Østby (2008).

14. Addison and Murshed (2006); Murshed (2002).

15. Hirshleifer (1995).

16. Lipset (1960).

17. Hegre, et al. (2001).

18. Addison, Le Billon, and Murshed (2002).

19. Tadjoeddin (2003).

20. Tadjoeddin, Suharyo, and Mishra (2003).

21. Lipset (1960).

22. Tadjoeddin and Murshed (2007).

\section{References}

Addison, T., P. Le Billon, and S.M. Murshed. 2002. “Conflict in Africa: The Cost of Peaceful Behaviour.” Journal of African Economies, Vol. 11, No. 3, pp. 365-386.

Addison, T. and S.M. Murshed. 2006. “The Social Contract and Violent Conflict,” pp. 137-163 in H. Yanacopoulos and J. Hanlon, eds. Civil War, Civil Peace. Oxford: Currey.

Akerlof, G. and R.E. Kranton. 2000. “Economics and Identity,” Quarterly Journal of Economics, Vol. 115, No. 3, pp. 715-753.

Collier, P. 2007. The Bottom Billion: Why the Poorest Countries are Failing and What Can Be Done About It. Oxford: Oxford University Press.

Collier, P. and A. Hoeffler. 2004. "Greed and Grievance in Civil Wars.” Oxford
Economic Papers, Vol. 56, No. 4, pp. 563-595.

Collier, P., L. Elliot, H. Hegre, A. Hoeffler, M. Reynal-Querol, and N. Sambanis. 2003. Breaking the Conflict Trap: Civil War and Development Policy. Washington, DC: World Bank.

Esteban, J.-M. and D. Ray. 1994. "On the Measurement of Polarization." Econometrica, Vol. 62, No. 4, pp. 819-851.

Fearon, J. 2005. "Primary Commodity Exports and Civil War.” Journal of Conflict Resolution, Vol. 49, No. 4, pp. 483-507.

Gurr, T.R. 1970. Why Men Rebel. Princeton, NJ: Princeton University Press.

Hegre, H., T. Ellingsen, S. Gates, and N.P. Gleditsch. 2001. “Towards a Democratic Civil Peace? Democracy, Civil Change, and Civil War 1816-1992.” American Political Science Review, Vol. 95, No. 1, pp. 17-33.

Hirshleifer, J. 1995. “Anarchy and its Breakdown.” Journal of Political Economy, Vol. 103, No. 1, pp. 26-52.

Humphreys, M. 2005. "Natural Resources, Conflict, and Conflict Resolution. Uncovering the Mechanisms.” Journal of Conflict Resolution, Vol. 49, No. 4, pp. 508-537.

Lipset, S. 1960. Political Man: The Social Bases of Politics. New York: Doubleday.

Lujala, P., N.P. Gleditsch, and E. Gilmore. 2005. “A Diamond Curse? Civil War and a Lootable Resource.” Journal of Conflict Resolution, Vol. 49, No. 4, pp. 538-562.

Montalvo, J.G. and M. Reynal-Querol. 2005. "Ethnic Diversity and Economic Development.” Journal of Development Economics, Vol. 76, No. 2, pp. 293-323.

Murshed, S.M. 2002. “Civil War, Conflict and Underdevelopment.” Journal of Peace Research, Vol. 39, No. 4, pp. 387-393.

Murshed, S.M. 2004. "When Does Natural Resource Abundance Lead to a Resource Curse.” IIED-EEP Working Paper 04-01.

Murshed, S.M. and M.Z. Tadjoeddin. 2008. "Revisiting the Greed and Grievance Explanations for Violent Conflict.” Journal of International Development, forthcoming.

Olson, M. 1965. The Logic of Collective Action. Cambridge, MA: Harvard University Press.

Østby, G. 2008. “Polarization, Horizontal Inequalities and Civil Conflict.” Journal of Peace Research, Vol. 45, No. 2, pp. 143-162.

Ross, M.L. 2003. “Oil, Drugs and Diamonds: The Varying Role of Natural Resources in Civil Wars,” pp. 47-70 in K. Ballentine and J. Sherman, eds. The Political Economy of Armed Conflict: Beyond Greed and Grievance. Boulder, CO: Lynne Rienner.

Ross, M.L. 2004. “What Do We Know About Natural Resources and Civil Wars?” Journal of Peace Research, Vol. 41, No. 3, pp. 337-356.

Sen, A.K. 2006. Identity and Violence: The Illusion of Destiny. New York: Norton. Stewart, F. 2000. “Crisis Prevention: Tackling Horizontal Inequalities.” Oxford Development Studies, Vol. 28, No. 3, pp. 245-262. 
(c) www.epsjournal.org.uk - Vol. 4, No. 1 (2009)

Tadjoeddin, M.Z. 2003. “Communal Conflicts and Horizontal Inequalities in Indonesia: Dynamics and Consequences.” Paper presented at the IPSK-CNRS Group Meeting on Conflict, LIPI Jakarta, 15 January 2003.

Tadjoeddin, M.Z. and S.M. Murshed. 2007. "Socioeconomic Determinants of Everyday Violence in Indonesia: An Empirical Investigation of Javanese Districts, 1994-2003.” Journal of Peace Research, Vol. 44, No. 6, pp. 689-707.

Tadjoeddin, M.Z., W.I. Suharyo, and S. Mishra. 2003. "Aspiration to Inequality: Regional Disparity and Centre-Regional Conflicts in Indonesia.” Paper presented at the UNU/WIDER Conference on Spatial Inequality in Asia, Tokyo, Japan, 2829 March 2003. 